\title{
Article \\ Plasma-Catalytic Process of Hydrogen Production from Mixture of Methanol and Water
}

\author{
Bogdan Ulejczyk ${ }^{1, *}$, tukasz Nogal $^{2}{ }^{\circledR}$, Paweł Jóźwik ${ }^{3} \oplus$, Michał Młotek $^{1}$ and Krzysztof Krawczyk $^{1}$ \\ 1 Faculty of Chemistry, Warsaw University of Technology, Noakowskiego 3, 00-664 Warsaw, Poland; \\ michal.mlotek@pw.edu.pl (M.M.); kraw@ch.pw.edu.pl (K.K.) \\ 2 Faculty of Electrical Engineering, Warsaw University of Technology, \\ Pl. Politechniki 1, 00-661 Warsaw, Poland; lukasz.nogal@ien.pw.edu.pl \\ 3 Faculty of Advanced Technologies and Chemistry, Military University of Technology, \\ Gen. S. Kaliskiego 2, 00-908 Warsaw, Poland; pjozwik@wat.edu.pl \\ * Correspondence: bulejczyk@ch.pw.edu.pl
}

Citation: Ulejczyk, B.; Nogal, Ł.; Jóźwik, P.; Młotek, M.; Krawczyk, K. Plasma-Catalytic Process of

Hydrogen Production from Mixture of Methanol and Water. Catalysts 2021, 11, 864. https://doi.org/10.3390/ catal11070864

Academic Editors: Jacek Tyczkowski and Hanna Kierzkowska-Pawlak

Received: 24 June 2021

Accepted: 18 July 2021

Published: 19 July 2021

Publisher's Note: MDPI stays neutral with regard to jurisdictional claims in published maps and institutional affiliations.

Copyright: (C) 2021 by the authors. Licensee MDPI, Basel, Switzerland. This article is an open access article distributed under the terms and conditions of the Creative Commons Attribution (CC BY) license (https:// creativecommons.org/licenses/by/ $4.0 /)$.

\begin{abstract}
In the present work the process of hydrogen production was conducted in the plasmacatalytic reactor, the substrates were first treated with plasma and then introduced into the catalyst bed. Plasma was produced by a spark discharge. The discharge power ranged from 15 to $46 \mathrm{~W}$. The catalyst was metallic nickel supported on $\mathrm{Al}_{2} \mathrm{O}_{3}$. The catalyst was active from a temperature of $400{ }^{\circ} \mathrm{C}$. The substrate flow rate was $1 \mathrm{~mol} / \mathrm{h}$ of water and $1 \mathrm{~mol} / \mathrm{h}$ of methanol. The process generated $\mathrm{H}_{2}$, $\mathrm{CO}, \mathrm{CO}_{2}$ and $\mathrm{CH}_{4}$. The gas which formed the greatest amount was $\mathrm{H}_{2}$. Its concentration in the gas was $\sim 60 \%$. The conversion of methanol and the production of hydrogen in the plasma-catalytic reactor were higher than in the plasma and catalytic reactors. The synergy effect of the interaction of two environments, i.e., plasma and the catalyst, was observed. The highest hydrogen production was $1.38 \mathrm{~mol} / \mathrm{h}$ and the highest methanol conversion was $64 \%$. The increased in the discharge power resulted in increasing methanol conversion and hydrogen production.
\end{abstract}

Keywords: plasma; catalyst; methanol; hydrogen; spark; discharge

\section{Introduction}

Plasma-catalytic reactors are complex systems in which chemical reactions and the effect of plasma on a catalyst must be taken into account. Various plasma-catalytic systems are used. A catalyst may be located in a plasma zone [1-7], an electrode may be the catalyst $[8,9]$, and often the catalyst is located outside the plasma zone [1,10-18]. This way of placing the catalyst prevents the destruction of the catalyst by plasma and the disturbance of the discharge. Especially catalysts in which the active phase is a metal capable of conducting an electric current on the surface and lead to a short circuit.

Plasma-catalytic reactors are used to improve the selectivity and efficiency of chemical processes. Such reactors combine the advantages of plasma and a catalyst. In plasma, in collisions with high-energy electrons very reactive radicals are formed, and the catalyst is subjected to selectively desired chemical reactions. As a result of introducing the catalyst into the plasma reactor, the conversion increases, which results in a reduction of the energy cost of the process. Processes such as gas purification [1-3], hydrogen production [5,7], Fischer-Tropsch synthesis [6] are carried out in plasma-catalytic reactors.

In this work, a plasma-catalytic reactor was used to generate hydrogen from a mixture of water and methanol place:

$$
\mathrm{CH}_{3} \mathrm{OH}+\mathrm{H}_{2} \mathrm{O} \leftrightarrows \mathrm{CO}_{2}+\mathrm{H}_{2}
$$

However, other methods of producing hydrogen from methanol are also investigated, e.g., plasma, catalytic, and electrochemical [19-24]. 
The $\mathrm{H}_{2}$ production using methanol/water mixture is endothermic. The reaction enthalpy for the reactants in the gas phase is $131.57 \mathrm{~kJ} / \mathrm{mol}$, and for the reactants in the liquid phase it is $49.51 \mathrm{~kJ} / \mathrm{mol}$. The difference in enthalpy is due to the energy consumption for the evaporation of methanol and water.

Methanol and water have several advantages as hydrogen sources. They are easy to transport as liquids. Water is a commonly available resource. Methanol can be obtained from biomass. The energy of the bonds in methanol is 3.63, 4.08, and $4.38 \mathrm{eV}$ [25], and in water $5.10 \mathrm{eV}$ [26] (Figure 1). Therefore, in collisions with high-energy electrons these molecules can dissociate, and radicals will be formed:
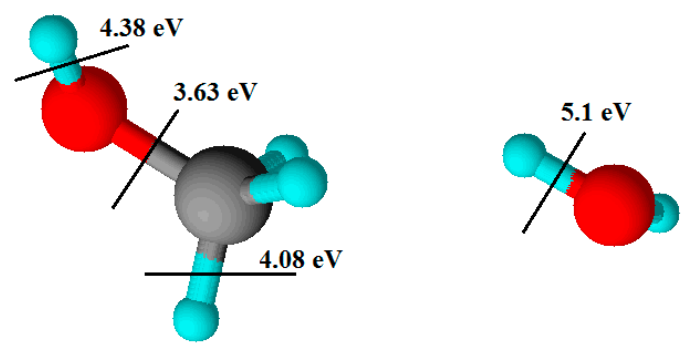

Figure 1. The energy bond in methanol and water.

$$
\begin{aligned}
& \mathrm{CH}_{3} \mathrm{OH}+\mathrm{e} \rightarrow \mathrm{CH}_{2} \mathrm{OH}+\mathrm{H}+\mathrm{e} \\
& \mathrm{CH}_{3} \mathrm{OH}+\mathrm{e} \rightarrow \mathrm{CH}_{3} \mathrm{O}+\mathrm{H}+\mathrm{e} \\
& \mathrm{CH}_{3} \mathrm{OH}+\mathrm{e} \rightarrow \mathrm{CH}_{3}+\mathrm{OH}+\mathrm{e} \\
& \mathrm{H}_{2} \mathrm{O}+\mathrm{e} \rightarrow \mathrm{OH}+\mathrm{H}+\mathrm{e}
\end{aligned}
$$

In this work, plasma was produced by a spark discharge. This discharge consists of many discharge channels in which the electron density reaches $10^{17} \mathrm{~cm}^{-1}$ [27]. Not all collisions lead to dissociation. Most of the collision raises the internal energy of water and methanol. There are many electrons, they are small and mobile, so molecules can collide with them many times and be excited to another energy state. After obtaining sufficiently high energy, they can dissociate, and methanol can also decompose:

$$
\mathrm{CH}_{3} \mathrm{OH} \rightarrow \mathrm{CO}+2 \mathrm{H}_{2}
$$

The return of the excited molecules to lower energy states is accompanied by the emission of photons, which allow photochemical reactions to take place on photocatalysts. Nickel deposited on carriers has photocatalytic properties [28-30]. Nickel catalysts also show catalytic activity in the process of steam reforming of methanol [31-33]. A catalyst with a metallic nickel content of $2.5 \%$ by weight was used in the tests.

Other metals also have catalytic properties in the steam reforming of methanol. There are, for example, platinum [34], gold [35], and copper catalysts [36]. However nickel is cheaper than noble metals. A copper catalyst's stability is poor [36].

\section{Results and Discussion}

\subsection{Catalytic Reactor}

The activity of the catalyst used in the conducted process was observed starting from the temperature of $400{ }^{\circ} \mathrm{C}$. The products of the catalytic process included $\mathrm{H}_{2}, \mathrm{CH}_{4}, \mathrm{CO}$, and $\mathrm{CO}_{2}$ (Table 1$)$. In the studied temperature range $\left(400-600{ }^{\circ} \mathrm{C}\right)$, the concentration of $\mathrm{H}_{2}$ in the cooled gases was high and ranged from 60.1 to $60.8 \%$. The $\mathrm{CO}$ concentration ranged from 15.3 to $24.2 \%$. The $\mathrm{CO}_{2}$ concentration ranged from 5.4 to $10.6 \%$. The $\mathrm{CH}_{4}$ concentration ranged from 0.3 to $0.4 \%$. In addition to the products, the cooled gas also contained water vapor $(\sim 2 \%)$ and methanol $(\sim 10 \%)$. 
Table 1. The concentration of products in the cooled gases.

\begin{tabular}{|c|c|c|c|c|c|c|}
\hline \multirow{2}{*}{ Reactor } & \multirow{2}{*}{ Power, W } & \multirow{2}{*}{ Temperature, ${ }^{\circ} \mathrm{C}$} & \multicolumn{4}{|c|}{ Concentration, $\%$} \\
\hline & & & $\mathbf{H}_{2}$ & $\mathrm{CO}$ & $\mathrm{CO}_{2}$ & $\mathrm{CH}_{4}$ \\
\hline \multirow{5}{*}{ Catalytic } & \multirow{5}{*}{-} & 400 & 60.1 & 24.2 & 3.5 & 0.3 \\
\hline & & 450 & 60.6 & 20.3 & 6.8 & 0.3 \\
\hline & & 500 & 61.0 & 18.5 & 8.0 & 0.4 \\
\hline & & 550 & 61.4 & 15.3 & 10.4 & 0.4 \\
\hline & & 600 & 60.8 & 18.9 & 7.7 & 0.4 \\
\hline \multirow{5}{*}{ Plasma-catalytic } & \multirow{5}{*}{15} & 400 & 59.2 & 25.5 & 2.7 & 0.6 \\
\hline & & 450 & 60.2 & 21.2 & 6.1 & 0.5 \\
\hline & & 500 & 60.5 & 19.3 & 7.5 & 0.6 \\
\hline & & 550 & 60.9 & 17.1 & 9.1 & 0.6 \\
\hline & & 600 & 60.4 & 18.8 & 7.8 & 0.6 \\
\hline \multirow{5}{*}{ Plasma-catalytic } & \multirow{5}{*}{30} & 400 & 59.4 & 22.1 & 5.4 & 1.1 \\
\hline & & 450 & 59.8 & 21.6 & 5.8 & 0.9 \\
\hline & & 500 & 60.0 & 19.5 & 7.4 & 1.1 \\
\hline & & 550 & 60.1 & 18.2 & 8.3 & 1.2 \\
\hline & & 600 & 59.0 & 21.9 & 5.4 & 1.3 \\
\hline \multirow{5}{*}{ Plasma-catalytic } & \multirow{5}{*}{46} & 400 & 59.4 & 22.1 & 5.4 & 1.1 \\
\hline & & 450 & 59.7 & 21.6 & 5.8 & 0.9 \\
\hline & & 500 & 60.0 & 19.5 & 7.3 & 1.1 \\
\hline & & 550 & 60.0 & 18.1 & 8.3 & 1.2 \\
\hline & & 600 & 58.9 & 21.9 & 5.4 & 1.3 \\
\hline
\end{tabular}

The high concentration of $\mathrm{CO}$ indicates that methanol decomposes on the nickel catalyst (R6). Then $\mathrm{CO}_{2}$ is formed in the water-gas shift reaction:

$$
\mathrm{CO}+\mathrm{H}_{2} \mathrm{O} \leftrightarrows \mathrm{CO}_{2}+\mathrm{H}_{2}
$$

CO can also be converted to methane:

$$
\mathrm{CO}+3 \mathrm{H}_{2} \leftrightarrows \mathrm{CH}_{4}+\mathrm{H}_{2} \mathrm{O}
$$

The methanation (R8) is of minor importance as it requires four molecules, so it is more difficult to carry out than the water-gas shift reaction. Additionally, the amount of water vapor is greater than the amount of hydrogen. This composition of the reaction mixture favors the water-gas shift reaction (R7), which is the desired reaction because it is responsible for the increase in hydrogen production.

Figures 2 and 3 show the effect of temperature on the methanol conversion and hydrogen production in the catalytic reactor. They show that the methanol conversion and hydrogen production reached a maximum at $500{ }^{\circ} \mathrm{C}$.

\subsection{Plasma Reactor}

The gaseous products generated in the spark discharge from the methanol and water mixture were $\mathrm{H}_{2}, \mathrm{CH}_{4}, \mathrm{CO}$, and $\mathrm{CO}_{2}$ (Figure 4a). The concentration of $\mathrm{H}_{2}$ in the cooled gases was high in all conditions and ranged from 58.0 to $58.9 \%$. The second product in terms of concentration in the cooled gases was $\mathrm{CO}$. Its concentration ranged from 15.3 to $24.2 \%$. The concentration of $\mathrm{CO}$ was correlated with the concentration of $\mathrm{CO}_{2}$. When the $\mathrm{CO}$ concentration was the highest then the $\mathrm{CO}_{2}$ concentration had the lowest values, $3.5 \%$. When the $\mathrm{CO}$ concentration was the lowest, then the $\mathrm{CO}_{2}$ concentration was the highest, $10.6 \%$. The $\mathrm{CH}_{4}$ concentration ranged from 1.0 to $1.3 \%$. 


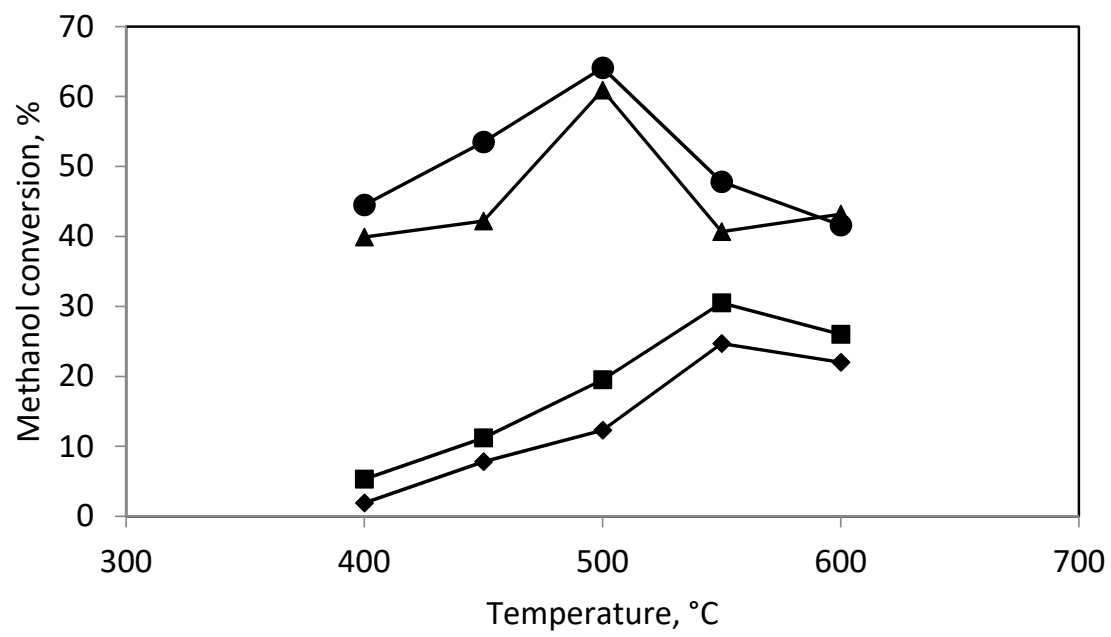

Figure 2. The conversion of methanol in: $(\downarrow)$ catalytic reactor; ( $\mathbf{\square})$ plasma-catalytic reactor, $15 \mathrm{~W}$ of power; ( $(\boldsymbol{\Lambda})$ plasma-catalytic reactor, $30 \mathrm{~W}$ of power; $(\bullet)$ plasma-catalytic reactor, $46 \mathrm{~W}$ of power.

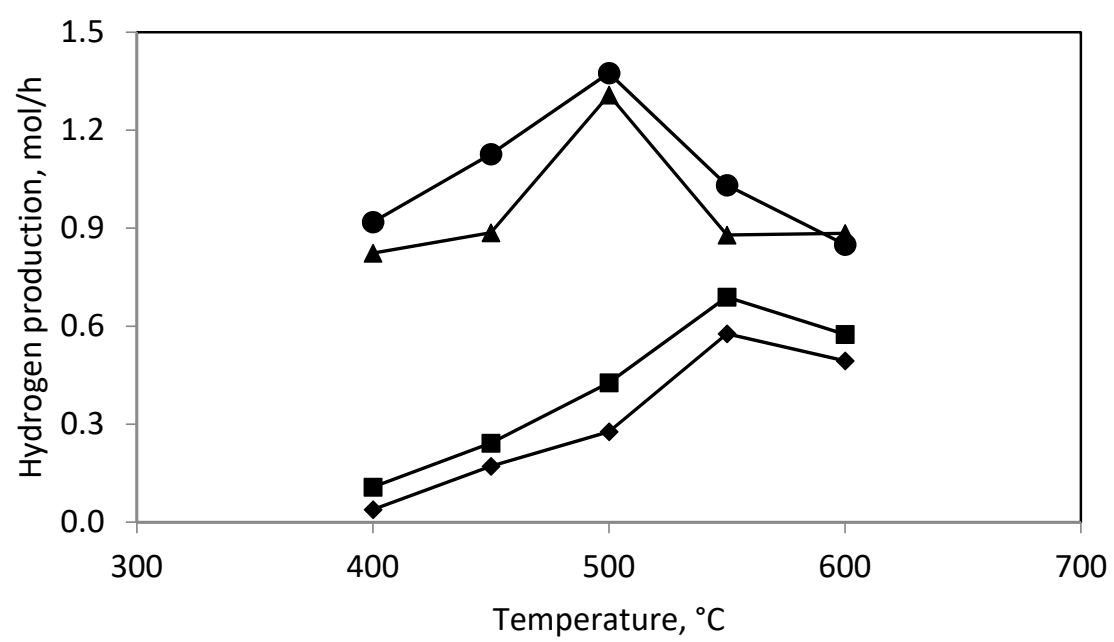

Figure 3. The hydrogen production in: $(\downarrow)$ catalytic reactor; $(\boldsymbol{\square})$ plasma-catalytic reactor, $15 \mathrm{~W}$ of power; $(\boldsymbol{\Lambda})$ plasma-catalytic reactor, $30 \mathrm{~W}$ of power; $(\bullet)$ plasma-catalytic reactor, $46 \mathrm{~W}$ of power.

The high concentration of $\mathrm{CO}$ results from the mechanism of an initiation reaction in plasma, i.e., the collision of molecules with high-energy electrons. $\mathrm{CH}_{2} \mathrm{OH}$ and $\mathrm{CH}_{3} \mathrm{O}$ radicals are formed from methanol mostly because it has the highest number of bonds with hydrogen (one $\mathrm{O}-\mathrm{H}$ and three $\mathrm{C}-\mathrm{H}$ ). These radicals are in mutual equilibrium [37]:

$$
\mathrm{CH}_{2} \mathrm{OH}^{\cdot} \leftrightarrows \mathrm{CH}_{3} \mathrm{O}^{\circ}
$$

Reactions of them lead to the formation of formaldehyde [38-42]:

$$
\begin{aligned}
& \mathrm{CH}_{2} \mathrm{OH}^{-}+\mathrm{hv} \rightarrow \mathrm{CH}_{2} \mathrm{O}+\mathrm{H}^{\cdot} \\
& \mathrm{CH}_{3} \mathrm{O}^{-}+\mathrm{hv} \rightarrow \mathrm{CH}_{2} \mathrm{O}+\mathrm{H}^{\cdot} \\
& \mathrm{CH}_{3} \mathrm{O}^{-}+\mathrm{hv} \rightarrow \mathrm{CH}_{3}+\mathrm{O} \\
& \mathrm{CH}_{2} \mathrm{OH}^{-}+\mathrm{H}^{-} \rightarrow \mathrm{CH}_{2} \mathrm{O}+\mathrm{H}_{2} \\
& \mathrm{CH}_{2} \mathrm{OH}^{-}+\mathrm{OH}^{\cdot} \rightarrow \mathrm{CH}_{2} \mathrm{O}+\mathrm{H}_{2} \mathrm{O} \\
& \mathrm{CH}_{3} \mathrm{O}^{-}+\mathrm{H}^{-} \rightarrow \mathrm{CH}_{2} \mathrm{O}+\mathrm{H}_{2} \\
& \mathrm{CH}_{3} \mathrm{O}^{\circ}+\mathrm{OH}^{\cdot} \rightarrow \mathrm{CH}_{2} \mathrm{O}+\mathrm{H}_{2} \mathrm{O}
\end{aligned}
$$




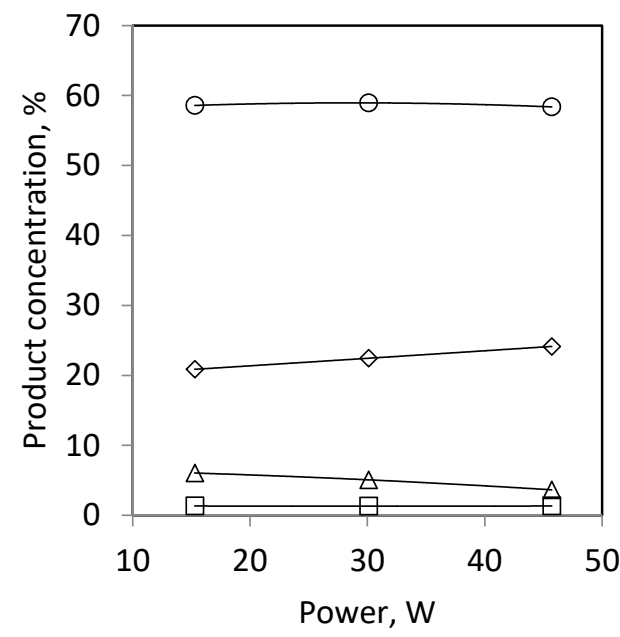

(a)

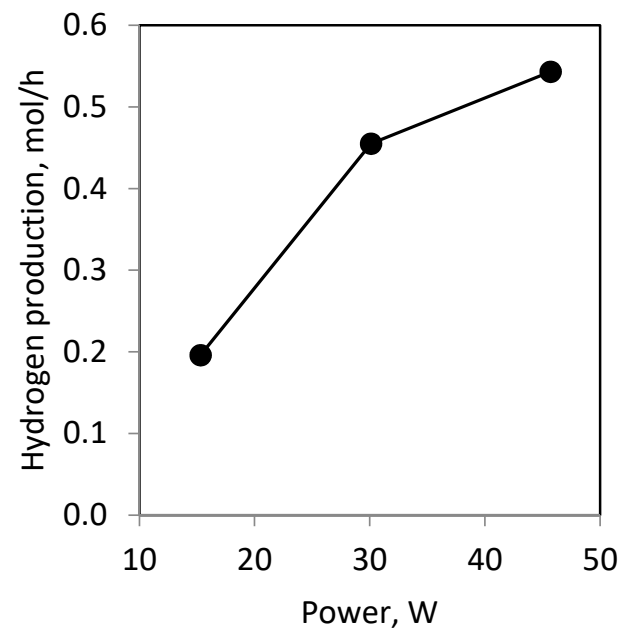

(c)

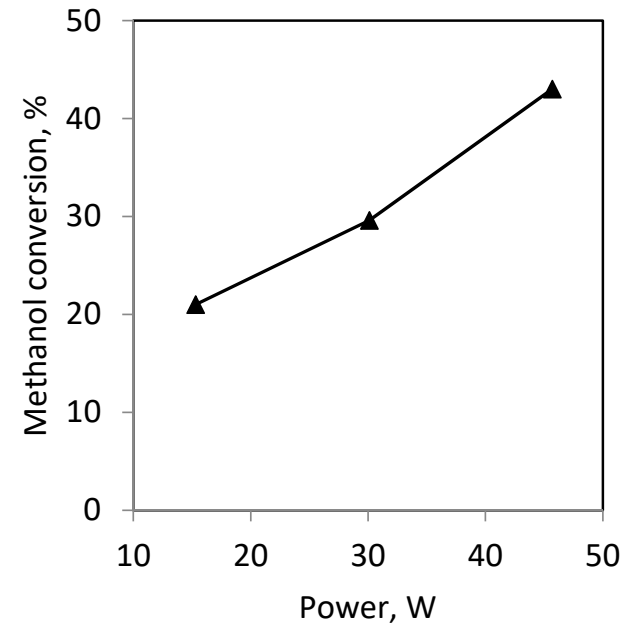

(b)

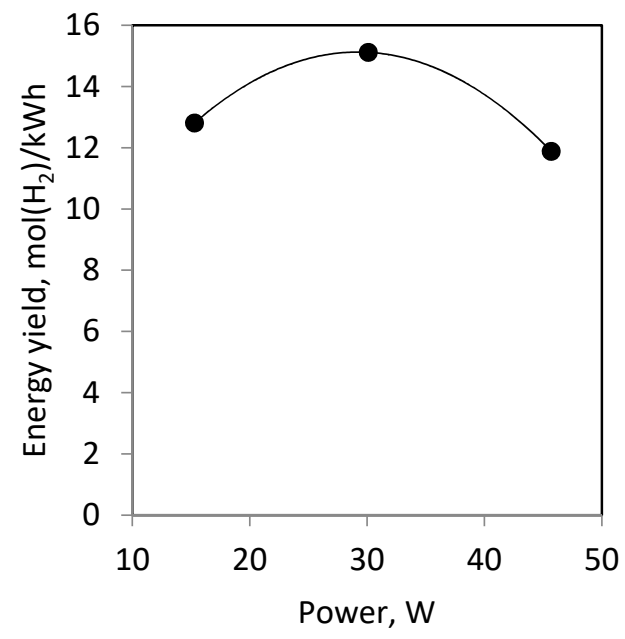

(d)

Figure 4. The influence of the discharge power on the operation of the plasma reactor. (a) The concentration of: $(\bigcirc)$ hydrogen; $(\diamond)$ carbon monoxide; $(\Delta)$ carbon dioxide and $(\square)$ methane in the gas; (b) methanol conversion; (c) hydrogen production; (d) energy yield.

Formaldehyde in plasma is rapidly decomposed [43-45]:

$$
\begin{aligned}
& \mathrm{CH}_{2} \mathrm{O}+\mathrm{hv} \rightarrow \mathrm{CO}+\mathrm{H}_{2} \\
& \mathrm{CH}_{2} \mathrm{O}+\mathrm{hv} \rightarrow \mathrm{CHO}+\mathrm{H}^{\prime} \\
& \mathrm{CH}_{2} \mathrm{O}+\mathrm{OH}^{\cdot} \rightarrow \mathrm{CHO}+\mathrm{H}_{2} \mathrm{O} \\
& \mathrm{CH}_{2} \mathrm{O}+\mathrm{H}^{\cdot} \rightarrow \mathrm{CHO}^{\circ}+\mathrm{H}_{2}
\end{aligned}
$$

Formyl radical is unstable and decomposes within $1 \mathrm{~ms}$ [46]:

$$
\mathrm{CHO} \rightarrow \mathrm{CO}+\mathrm{H}^{\circ}
$$

$\mathrm{CO}_{2}$ can be produced by the reaction with water vapor (R7), atomic oxygen, hydroxyl radical, or hydrogen peroxide [47-50]: 


$$
\begin{aligned}
& \mathrm{H}^{\cdot}+\mathrm{OH}^{\cdot} \rightarrow \mathrm{H}_{2}+\mathrm{O} \\
& \mathrm{OH}^{\cdot}+\mathrm{OH}^{\cdot} \rightarrow \mathrm{H}_{2} \mathrm{O}+\mathrm{O} \\
& \mathrm{CO}+\mathrm{O} \rightarrow \mathrm{CO}_{2} \\
& \mathrm{CO}+\mathrm{OH}^{\cdot} \rightarrow \mathrm{CO}_{2}+\mathrm{H}^{\cdot} \\
& \mathrm{OH}+\mathrm{OH}^{\cdot} \rightarrow \mathrm{H}_{2} \mathrm{O}_{2} \\
& \mathrm{CO}+\mathrm{H}_{2} \mathrm{O}_{2} \rightarrow \mathrm{CO}_{2}+\mathrm{H}_{2} \mathrm{O}
\end{aligned}
$$

$\mathrm{CH}_{4}$ is formed by reactions with methyl radical [51-55]:

$$
\begin{aligned}
& \mathrm{CH}_{3}+\mathrm{H}_{2} \mathrm{O} \rightarrow \mathrm{CH}_{4}+\mathrm{OH}^{-} \\
& \mathrm{CH}_{3}^{-}+\mathrm{H}^{-} \rightarrow \mathrm{CH}_{4} \\
& \mathrm{CH}_{3}^{-}+\mathrm{CH}_{3} \mathrm{OH} \rightarrow \mathrm{CH}_{4}+\mathrm{CH}_{3} \mathrm{O} \\
& \mathrm{CH}_{3}+\mathrm{CH}_{3} \mathrm{OH} \rightarrow \mathrm{CH}_{4}+\mathrm{CH}_{2} \mathrm{OH} \\
& \mathrm{CH}_{3}+\mathrm{CH}_{3} \mathrm{O} \rightarrow \mathrm{CH}_{4}+\mathrm{CH}_{2} \mathrm{O} \\
& \mathrm{CH}_{3}+\mathrm{CH}_{2} \mathrm{OH} \rightarrow \mathrm{CH}_{4}+\mathrm{CH}_{2} \mathrm{O} \\
& \mathrm{CH}_{3}+\mathrm{CH}_{2} \mathrm{O} \rightarrow \mathrm{CH}_{4}+\mathrm{CHO}^{\circ} \\
& \mathrm{CH}_{3}+\mathrm{CHO}^{-} \rightarrow \mathrm{CH}_{4}+\mathrm{CO}
\end{aligned}
$$

Figure 4 shows the effect of the discharge power on the methanol conversion (Figure $4 \mathrm{~b}$ ) and hydrogen production (Figure 4c) in the plasma reactor. It shows that the methanol conversion and hydrogen production increased with increasing discharge power. The increase in the methanol conversion and hydrogen production with increasing discharge power is the expected effect. We observed a similar effect in our earlier work on ethanol steam reforming in the dielectric barrier discharge. It is worth noting that the higher the discharge power, the greater the hydrogen production $(0.20 \mathrm{~mol} / \mathrm{h}$ and $0.46 \mathrm{~mol} / \mathrm{h}$ for $15 \mathrm{~W}$ and $30 \mathrm{~W}$, respectively). That is a two-fold increase in power resulted in a more than two-fold increase in the hydrogen production. A further increase in the discharge power to $46 \mathrm{~W}$, by $\sim 50 \%$, resulted in a much smaller increase in the hydrogen production, only to $0.54 \mathrm{~mol} / \mathrm{h}$, i.e., by $\sim 20 \%$. Therefore, at $30 \mathrm{~W}$ of the discharge power the energy yield reaches a maximum (Figure $4 \mathrm{~d}$ ).

\subsection{Plasma-Catalytic Reactor}

The gaseous products of the plasma-catalytic process included $\mathrm{H}_{2}, \mathrm{CH}_{4}, \mathrm{CO}$, and $\mathrm{CO}_{2}$ (Table 1). In the studied temperature range $\left(400-600{ }^{\circ} \mathrm{C}\right)$, the concentration of $\mathrm{H}_{2}$ in the cooled gases was high and ranged from 58.9 to $60.9 \%$. The $\mathrm{CO}_{2}$ concentration ranged from 2.7 to $9.1 \%$. The $\mathrm{CH}_{4}$ concentration ranged from 0.5 to $1.3 \%$.

In the plasma-catalytic reactor, the substrates first pass through the plasma zone where radicals are formed. The average residence time of the reactants in the plasma zone is $7 \mathrm{~ms}$. Then, after $40 \mathrm{~ms}$, the reactants are contacted with the catalyst. In comparison to the catalytic process, the reaction of methanol decomposition in the plasma-catalytic reactor is slower. This is due to the fact that the concentration of methanol in the stream of reactants fed into the catalyst bed is lower in the plasma-catalytic reactor than in the catalytic reactor. On the other hand, the reactions involving $\mathrm{CO}$ and $\mathrm{H}_{2}$ will run faster because $\mathrm{CO}$ and $\mathrm{H}_{2}$ are already present in the gases introduced to the catalyst bed. The obtained $\mathrm{CH}_{4}$ concentration in the plasma-catalytic reactor was higher than in the catalytic converter. However, it is surprising that the concentration of $\mathrm{CO}_{2}$ in the plasma-catalytic reactor is similar or even lower than in the catalytic reactor. This indicates that the conditions in the catalyst bed are not favorable for the water-gas shift reaction (R7) but favor the methanation (R8) or the Sabatier reaction (R36):

$$
\mathrm{CO}_{2}+4 \mathrm{H}_{2} \leftrightarrows \mathrm{CH}_{4}+2 \mathrm{H}_{2} \mathrm{O}
$$

In the plasma-catalytic reactor the methanol conversion and hydrogen production were higher than that for the plasma reactor or the catalytic reactor even though the unfavorable phenomenon of methane formation was observed. Figures 2 and 3 show 
the dependence of the methanol conversion and hydrogen production on the catalytic bed temperature and the discharge power. The methanol conversion and hydrogen production were maximum at $500-550{ }^{\circ} \mathrm{C}$ and increased with increasing discharge power (Figures 2 and 3 ) as it was observed for the plasma reactor. The increase in the discharge power from 15 to $30 \mathrm{~W}$ resulted in a significant increase in the methanol conversion and hydrogen production. In contrast, a further increase in the discharge power to $46 \mathrm{~W}$ caused a small increase in methanol conversion and hydrogen production.

\subsection{Catalyst Characteristic}

Figure 5 shows the EDX analysis of the fresh and used catalysts. The following elements $\mathrm{Al}, \mathrm{O}, \mathrm{Ni}, \mathrm{Ca}, \mathrm{Mg}$, and $\mathrm{Na}$ were present in the fresh catalyst. Nickel was introduced into the catalyst during its preparation. The remaining elements are the carrier components. The main component of the carrier was aluminum oxide. The remaining elements were found in small amounts. Calcium, magnesium, and sodium were $0.85,0.80$, and $0.17 \%$, respectively. $\mathrm{Al}, \mathrm{O}$, and $\mathrm{Ni}$ were evenly distributed on the surface of the fresh catalyst (Figure 6). The EDX dot mapping analysis of the surface of the used catalyst (Figure 7) indicates that there is no change in Ni dispersion under the influence of plasma.

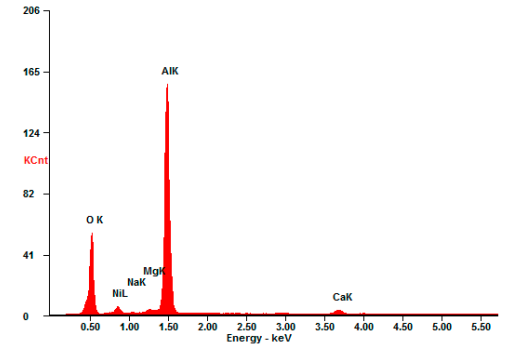

(a)

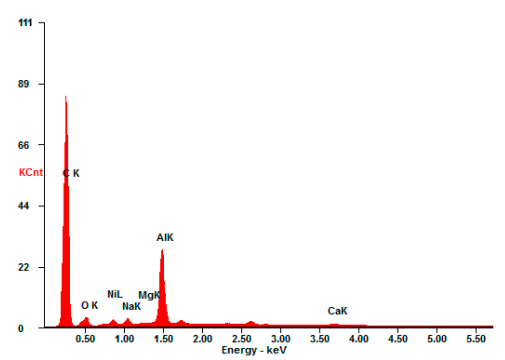

(b)

Figure 5. EDX spectrum of elemental microanalysis: (a) the fresh catalyst; (b) the used catalyst.

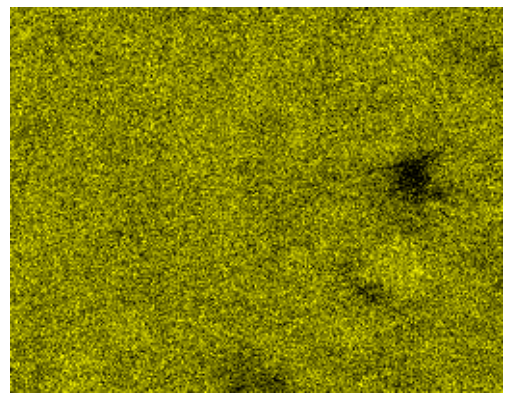

(a)

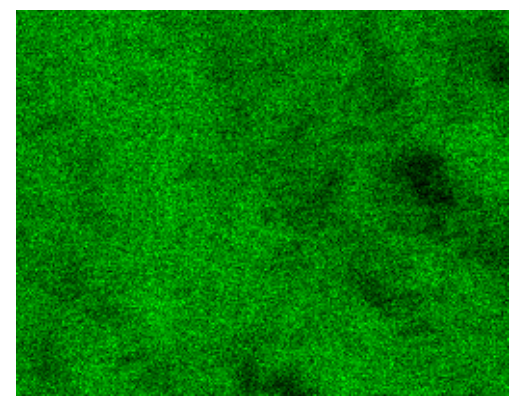

(b)

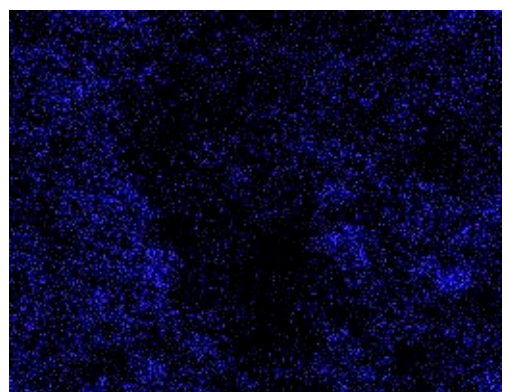

(c)

Figure 6. EDX dot mapping analysis of the surface of the fresh catalyst: (a) aluminum; (b) oxygen; (c) nickel.

The EDX spectrum showed the presence of carbon in the used catalyst (Figure 5b). Carbon covered the entire surface of the catalyst and the intensity of EDX signals from $\mathrm{Al}$, $\mathrm{O}$ and $\mathrm{Ni}$ were lower in the used catalyst than in the fresh catalyst (Figures 5-7).

The SEM micrographs of the fresh and used catalyst are shown in Figure 8. In the fresh catalyst, particles with a size of $\sim 1 \mu \mathrm{m}$ were visible on the surface. The morphology of the used catalyst was different. The catalyst surface were covered with a deposit of carbon nanofibers. This deposit was porous and gas permeable, therefore no reduction in the catalyst activity was observed during the tests. 


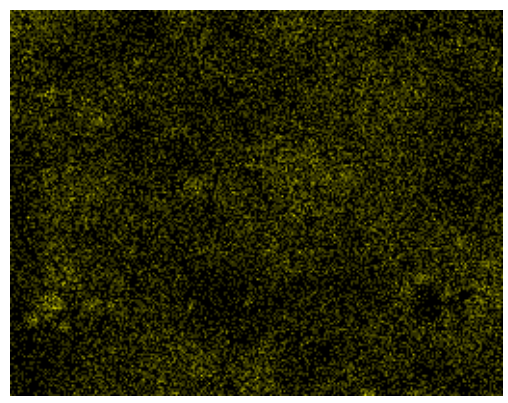

(a)

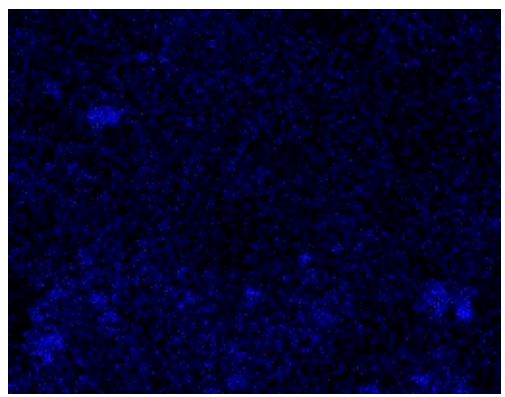

(c)

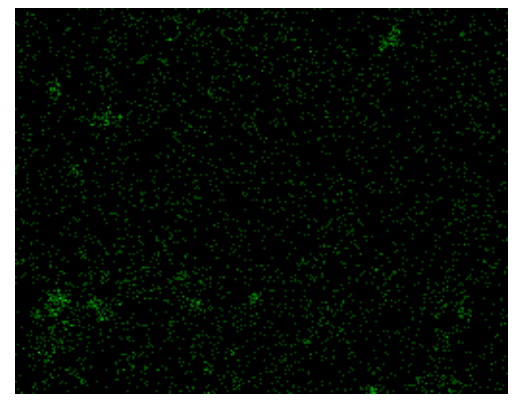

(b)

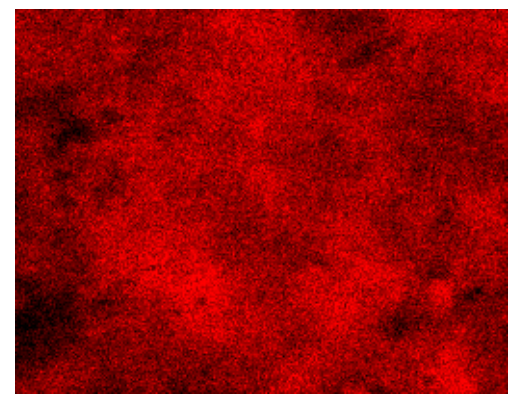

(d)

Figure 7. EDX dot mapping analysis of the surface of the used catalyst: (a) aluminum; (b) oxygen; (c) nickel; (d) carbon.

The carbon deposit could be formed in the following reactions [56]:

$$
\begin{array}{ll}
2 \mathrm{CO} \rightleftarrows \mathrm{C} \rightarrow \mathrm{CO}_{2} & (\text { R37 }) \\
\mathrm{CO} \rightarrow \mathrm{H}_{2} \rightleftarrows \mathrm{C} \rightarrow \mathrm{H}_{2} \mathrm{O} & (\text { R38) } \\
\mathrm{CO}_{2} \rightarrow 2 \mathrm{H}_{2} \rightleftarrows \mathrm{C} \rightarrow 2 \mathrm{H}_{2} \mathrm{O} & (\text { R39) }
\end{array}
$$
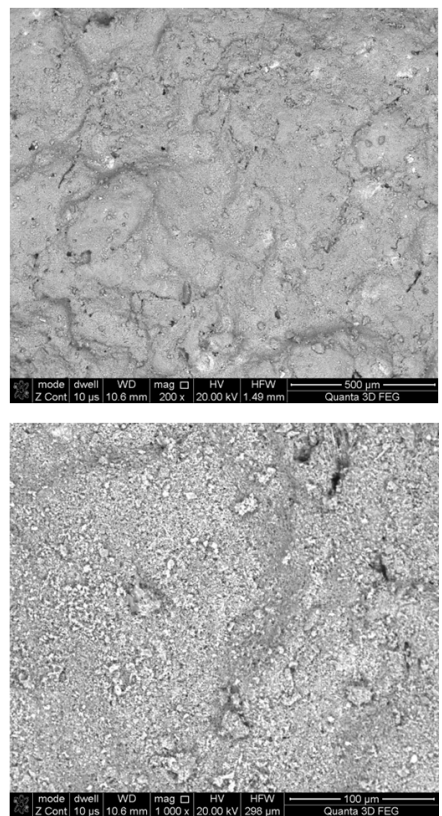

Figure 8. Cont.
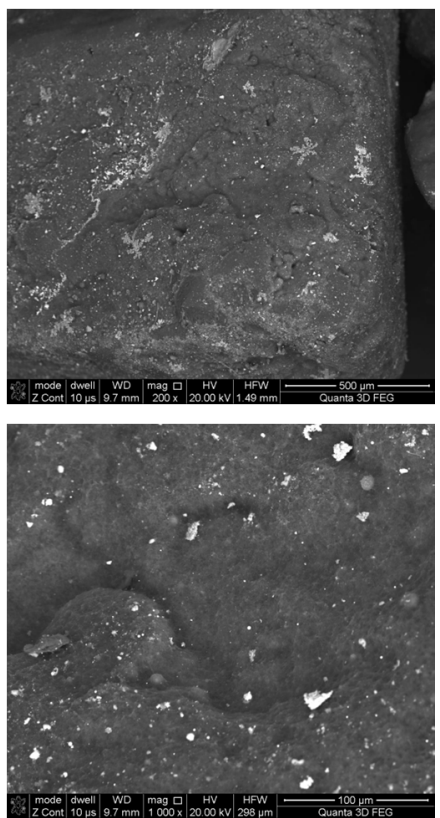

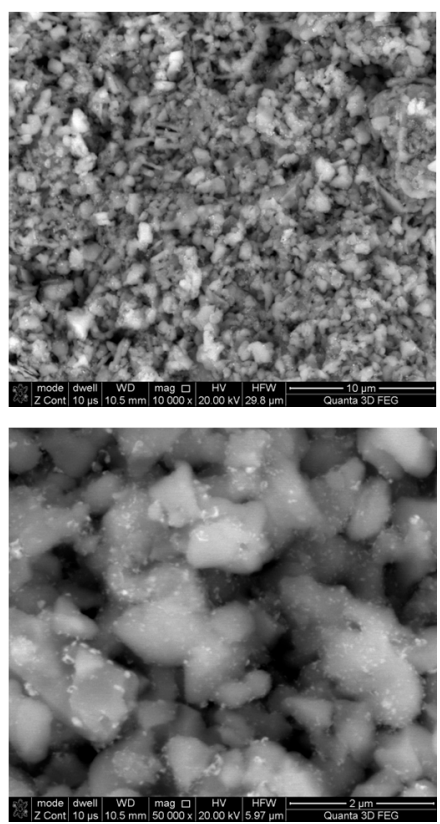

(a)
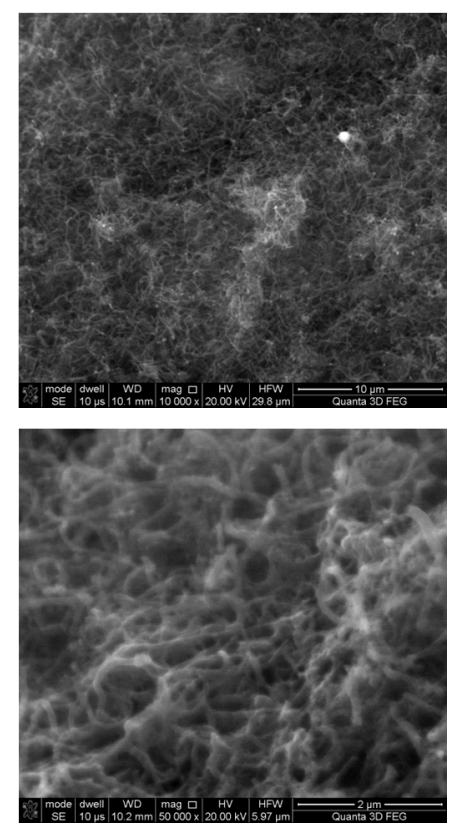

(b)

Figure 8. SEM images of: (a) the fresh catalyst; (b) the used catalyst.

The presence of $\mathrm{CO}$ in the gases introduced into the catalytic bed is favorable for both reactions. However, the presence of water vapor inhibits R38 and R39. While the temperature of $400-600{ }^{\circ} \mathrm{C}$ and the low content of $\mathrm{CO}_{2}$ in the gases introduced into the catalyst bed favor the Boudouard reaction (R37). Therefore, most likely this reaction is responsible for the formation of a deposit of carbon nanofibers.

In the catalyst used, there were local spherical particles showing an increased content of nickel and oxygen (Figure 9), also covered with a carbon deposit. The elevated oxygen content indicates that some part of nickel is oxidized. In the presence of water this is not surprising. Water can be decomposed on nickel catalysts and nickel can be oxidized [57]. The presence of nickel oxide may be advantageous because it makes the photochemical reactions run more efficiently [58]. Other metal oxides are photo-catalysts, on which the water splitting process takes place $[59,60]$.
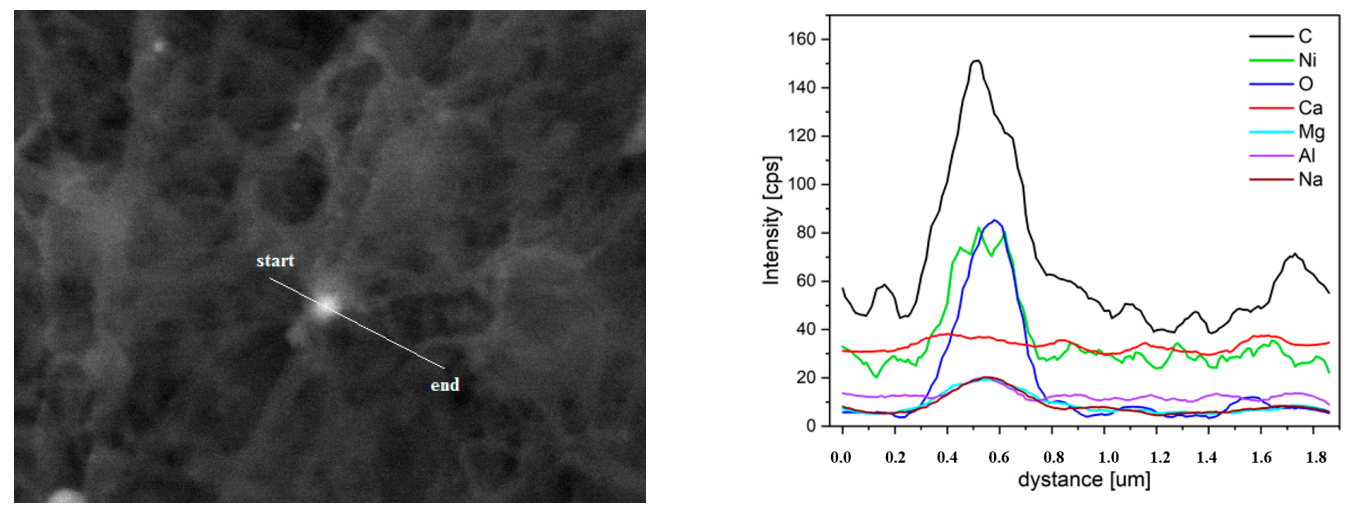

Figure 9. EDX linear scanning of the used catalyst.

\section{Materials and Methods}

Figure 10 presents the apparatus used during the experiments. The main part was a reactor with quartz casing of $100 \mathrm{~mm}$ in length and the internal diameter of $8 \mathrm{~mm}$. The electrodes were placed in $50 \mathrm{~mm}$ long quartz arms. The electrodes were made of $316 \mathrm{~L}$ 
grade stainless steel and had a diameter of $3.2 \mathrm{~mm}$. The seal between the electrodes and the casing was made of high-temperature silicone. A layer of quartz wool was placed over the electrodes. This layer increased the surface of the liquid evaporation and the mixing of the substrates vapors. One gram of the catalyst was placed under the electrodes. The distance between the ends of the electrodes and the catalyst was $10 \mathrm{~mm}$. The catalyst bed was heated by an electric furnace. The temperature of the catalyst bed was controlled in the range of 400 to $600{ }^{\circ} \mathrm{C}$.

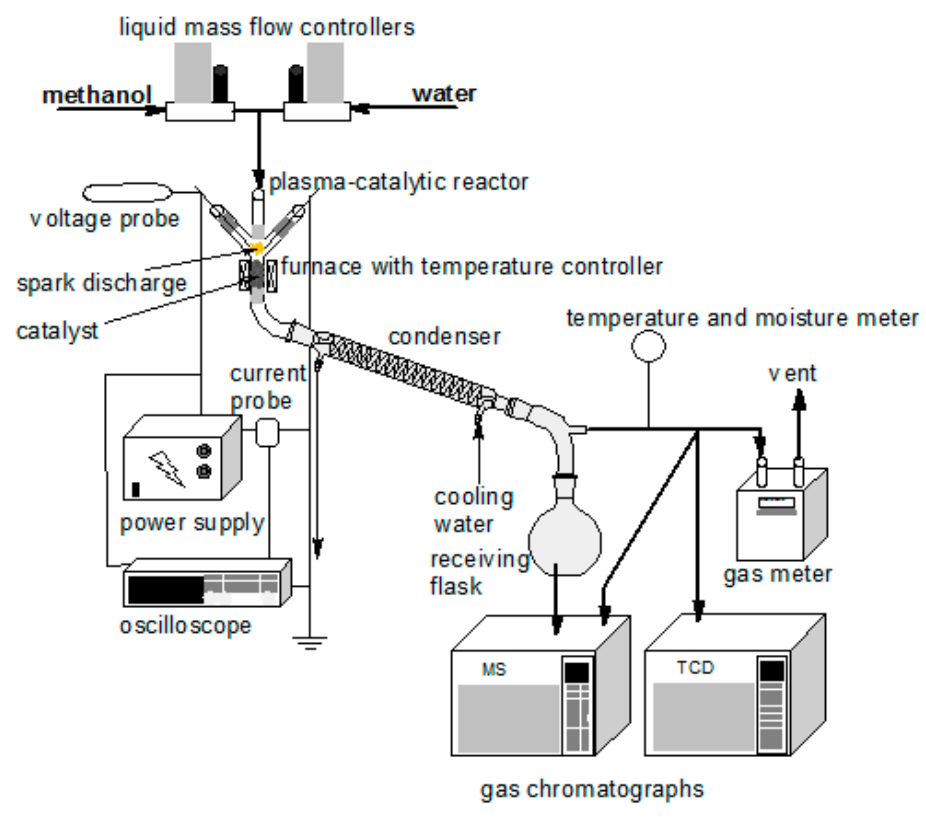

Figure 10. A schematic diagram of the experimental setup.

The $\mathrm{Al}_{2} \mathrm{O}_{3}$ carrier was manufactured by INS Puławy, Poland. The carrier was impregnated with a solution of $\mathrm{Ni}\left(\mathrm{NO}_{3}\right)_{2} \cdot 6 \mathrm{H}_{2} \mathrm{O}$ (Avantor Performance Material Poland $\mathrm{SA}$ ) using incipient wetness method. The next steps of the catalyst preparation were: drying (24 h), calcination at $600{ }^{\circ} \mathrm{C}(24 \mathrm{~h})$, reduction at $400{ }^{\circ} \mathrm{C}(6 \mathrm{~h})$ under $\mathrm{H}_{2}$ flow and cooling to $40{ }^{\circ} \mathrm{C}$ under $\mathrm{H}_{2}$ flow. The obtained catalyst has the surface area $\left(\mathrm{S}_{\mathrm{BET}}\right)$ of $7.6 \mathrm{~m}^{2} / \mathrm{g}$ estimated by $\mathrm{N}_{2}$ physisorption method using ASAP 2020 (Micromeritics, Norcross, GA, USA). The morphology of the catalyst was determined with a Quanta 3D (FEG SEM) field emission gun scanning electron microscopy. The chemical composition was estimated using FEG SEM EDS spectrometer of $20 \mathrm{kV}$ acceleration voltage.

The substrates (water and methanol) flow rates were $1 \mathrm{~mol} / \mathrm{h}$ for each reagent and were controlled with liquid mass flow controllers (Bronkhorst/EIEWIN, Gliwice, Poland) calibrated to water and methanol.

The outlet gas was passed through a quartz fiber filter and cooled to $17-18{ }^{\circ} \mathrm{C}$ to condense water and methanol (measured by weigth). The gas flow rate was measured with the Illmer-Gasmesstechnik (Berlin, Germany) gas-meter, the temperature and water vapor content in the gases were measured with the Apar (Raszyn, Poland) AR236/2 sensor. The concentration of the gases was measured using the Hewlett-Packard (Palo Alto, CA, USA) 6890 gas chromatograph with the thermal conductivity detector. The composition of the liquid was measured with the Thermo Fisher Scientific (Waltham, MA, USA)Trace 1300 chromatograph equipped with the single quadrupole mass spectrometer. The same research methodology was used in our previous studies $[7,61]$.

The reactor was powered by alternating current with a frequency of $15.3 \mathrm{kHz}$ using the power supply constructed at the Faculty of Electrical Engineering of the Warsaw University of Technology. The discharge powers were 15, 30 and $46 \mathrm{~W}$.

The discharge was turned on when starting the feeding of the reactor with the substrates. The recording of the discharge parameters (i.e., voltage and current) using a Tek- 
tronix (Beaverton, OR, USA) TDS3032 oscilloscope with a Tektronix P6015A voltage probe and a Tektronix TCP202 current probe was conducted with an interval of $15 \mathrm{~min}$. Based on these measurements, the discharge power was calculated according to the formula (1):

$$
\mathrm{P}=\mathrm{f} \cdot \int \mathrm{U}(\mathrm{t}) \cdot \mathrm{I}(\mathrm{t}) \mathrm{dt}
$$

$\mathrm{P}$-discharge power, $\mathrm{W}$

$\mathrm{F}$-frequency, $\mathrm{Hz}$

U-voltage, $\mathrm{V}$

I-current, A

$\mathrm{t}$ - time, $\mathrm{s}$

The parameters used to assess the process of hydrogen production, i.e., concentration of products, hydrogen production, methanol conversion, and energy yield of hydrogen production were measured or calculated according to the formulas (2)-(4):

$$
\mathrm{W}\left[\mathrm{H}_{2}\right]=\mathrm{q} \cdot \mathrm{c} / \mathrm{V}
$$

$\mathrm{W}\left[\mathrm{H}_{2}\right]$-production of hydrogen, $\mathrm{mol} / \mathrm{h}$

$\mathrm{q}-$ gas flow rate $[\mathrm{STP}], \mathrm{dm}^{3} / \mathrm{h}$

c-concentration of hydrogen

$\mathrm{V}-$ molar volume of gas [STP], $\mathrm{dm}^{3} / \mathrm{mol}$

$$
X=\left(W_{\text {in }}[\mathrm{MeOH}]-W[\mathrm{MeOH}]\right) / \mathrm{W}_{\text {in }}[\mathrm{MeOH}] \cdot 100 \%
$$

$\mathrm{x}$-methanol conversion, $\%$

$\mathrm{W}_{\text {in }}[\mathrm{MeOH}]$-inlet methanol flow rate, $\mathrm{mol} / \mathrm{h}$

$\mathrm{W}[\mathrm{MeOH}]$-outlet methanol flow rate, $\mathrm{mol} / \mathrm{h}$

$\mathrm{V}-$ molar volume of gas under standard conditions, $\mathrm{dm}^{3} / \mathrm{mol}$

$$
\mathrm{Y}=\mathrm{W}\left[\mathrm{H}_{2}\right] /(1000 \cdot \mathrm{P})
$$

$\mathrm{Y}$-energy yield, $\operatorname{mol}\left(\mathrm{H}_{2}\right) / \mathrm{kWh}$

\section{Conclusions}

The plasma-catalytic reactor allowed to achieve higher hydrogen production and methanol conversion in comparison to the plasma reactor or the catalytic reactor. The methanol conversion and hydrogen production were dependent on the discharge power and the temperature of the catalytic bed. The best results were obtained when the catalytic bed temperature was $500-550{ }^{\circ} \mathrm{C}$. The conversion methanol and hydrogen production increased as the discharge power increased. However, while the increase in the discharge power from 15 to $30 \mathrm{~W}$ caused a large increase in the methanol conversion and hydrogen production, a further increase to $46 \mathrm{~W}$ was not very effective. Therefore, the discharge power of $30 \mathrm{~W}$ was optimal. For this power and the temperature of $500{ }^{\circ} \mathrm{C}$ methanol conversion and hydrogen production were $61 \%$ and $1.31 \mathrm{~mol} / \mathrm{h}$, respectively. The highest achieved values of methanol conversion and hydrogen production were slightly higher and amounted to $64 \%$ and $1.38 \mathrm{~mol} / \mathrm{h}$, respectively. They were obtained for the discharge power of $46 \mathrm{~W}$ and the temperature of $500{ }^{\circ} \mathrm{C}$.

Both in the plasma and on the catalyst the decomposition of methanol was the main reaction. Subsequent reactions leading to the formation of $\mathrm{CO}_{2}$ and $\mathrm{CH}_{4}$ occurred to a small extent. The presence of the catalyst was advantageous because it increased the importance of the subsequent reactions.

Author Contributions: Conceptualization, B.U.; methodology, B.U., M.M., P.J. and Ł.N.; validation, B.U., K.K., P.J. and M.M.; formal analysis, B.U.; investigation, B.U., P.J., Ł.N. and M.M.; resources, 
B.U., Ł.N. and P.J.; data curation, B.U.; writing—original draft preparation, B.U.; writing—review and editing, B.U.; supervision, K.K.; funding acquisition, K.K. All authors have read and agreed to the published version of the manuscript.

Funding: This research was funded by Warsaw University of Technology.

Data Availability Statement: Data will be made available by authors on request.

Conflicts of Interest: The authors declare no conflict of interest.

\section{References}

1. Schmidt-Szałowski, K.; Krawczyk, K.; Sentek, J.; Ulejczyk, B.; Górska, A.; Młotek, M. Hybrid plasma-catalytic systems for converting substances of high stability, greenhouse gases and VOC. Chem. Eng. Res. Des. 2011, 89, 2643-2654. [CrossRef]

2. Vega-Gonzalez, A.; Duten, X.; Sauce, S. Plasma-Catalysis for Volatile Organic Compounds Decomposition: Complexity of the Reaction Pathways during Acetaldehyde Removal. Catalysis 2020, 10, 1146.

3. Cimerman, R.; Cíbiková, M.; Satrapinskyy, L.; Hensel, K. The effect of packing material properties on tars removal by plasma catalysis. Catalysts 2020, 10, 1476. [CrossRef]

4. Krawczyk, K.; Młotek, M.; Ulejczyk, B.; Schmidt-Szałowski, K. Methane conversion with carbon dioxide in plasma-catalytic system. Fuel 2014, 117, 608-617. [CrossRef]

5. Ge, W.; Duan, X.; Li, Y.; Wang, B. Plasma catalyst synergy during methanol steam reforming in dielectric barrier discharge micro-plasma reactors for hydrogen production. Plasma Chem. Plasma Process. 2015, 35, 187-199. [CrossRef]

6. Govender, B.B.; Iwarere, S.A.; Ramjugarnath, D. Plasma-catalytic Fisher-Tropsch synthesis at very high pressure. Catalysts 2021, 19, 297. [CrossRef]

7. Ulejczyk, B.; Nogal, Ł.; Młotek, M.; Falkowski, P.; Krawczyk, K. Hydrogen production from ethanol using a special multi-segment plasma-catalytic reactor. J. Energy Inst. 2021, 95, 179-186. [CrossRef]

8. Magureanu, M.; Mandache, N.B.; Paevulescu, V.I.; Subrahmanyam, C.; Renken, A.; Kiwi-Minsker, L. Improved performance of non-thermal plasma reactor during decomposition of trichloroethylene: Optimization of the reactor geometry and introduction of catalytic electrode. Appl. Catal. B Environ. 2007, 74, 270-277. [CrossRef]

9. Krawczyk, K.; Jodzis, S.; Lamenta, A.; Kostka, K.; Schmidt-Szalowski, K. Study on decomposition of tetrachloromethane as a model substance in environment of spark discharge plasma. Przem. Chem. 2010, 8, 1101-1106.

10. Reda, E.; Jóźwik, P.; Krawczyk, K.; Młotek, M. Plasma-catalytic decomposition of cyclohexane in gliding discharge reactor. Appl. Catal. A Gen. 2015, 25, 150-158.

11. Shak, J.R.; Harrison, J.M.; Carreon, M.L. Ammonia plasma-catalytic synthesis using low melting point alloys. Catalysts 2018, $8,437$.

12. Młotek, M.; Ulejczyk, B.; Woroszył, J.; Walerczak, I.; Krawczyk, K. Purification of the gas after pyrolysis in coupled plasma-catalytic system. Pol. J. Chem. Technol. 2017, 19, 94-98. [CrossRef]

13. Du, C.M.; Ma, D.; Wu, J.; Lin, Y.; Xiao, W.; Ruan, J.; Huang, D. Plasma-catalysis reforming for $\mathrm{H}_{2}$ production from ethanol. Int. J. Hydrogen. Energy 2015, 40, 15398-15410. [CrossRef]

14. Młotek, M.; Ulejczyk, B.; Woroszył, J.; Krawczyk, K. Coupled Plasma-Catalytic System with Rang 19pr Catalyst for Conversion of Tar. Sci. Rep. 2019, 9, 13562. [CrossRef] [PubMed]

15. Młotek, M.; Ulejczyk, B.; Woroszył, J.; Krawczyk, K. Decomposition of Toluene in Coupled Plasma-Catalytic System. Ind. Eng. Chem. Res. 2020, 59, 4239-4244. [CrossRef]

16. Krawczyk, K.; Ulejczyk, B.; Song, H.K.; Lamenta, A.; Paluch, B.; Schmidt-Szałowski, K. Plasma-catalytic Reactor for Decomposition of Chlorinated Hydrocarbons. Plasma Chem. Plasma Process. 2009, 29, 27-41. [CrossRef]

17. Wang, B.; Mikhail, M.; Gavadias, S.; Tatoulian, M.; Da Costa, P.; Ognier, S. Improvement of the activity of $\mathrm{CO}_{2}$ methanation in a hybrid plasma-catalytic process in varying catalyst particle size or under pressure. J. $\mathrm{CO}_{2}$ Util. 2021, 46, 101471. [CrossRef]

18. Audemar, M.; Vallcorba, O.; Peral, I.; Thomann, J.S.; Przekora, A.; Pawlat, J.; Canal, C.; Ginalska, G.; Kwiatkowski, M.; Duday, D.; et al. Catalytic enrichment of plasma with hydroxyl radicals in the aqueous phase at room temperature. Catal. Sci. Technol. 2021, 11, 1430-1442. [CrossRef]

19. Mosinska, M.; Stępińska, N.; Maniukiewicz, W.; Rogowski, J.; Mierczynska-Vasilev, A.; Vasilev, K.; Szynkowska, M.I.; Mierczyński, P. Hydrogen production on Cu-Ni catalysts via the oxy-steam reforming of methanol. Catalysts 2020, 10, 273. [CrossRef]

20. Perez-Larios, A.; Rico, J.L.; Anaya-Esparza, L.M.; Gonzalez Vargas, O.A.; Gonzalez-Silva, N.; Gomez, R. Hydrogen production from aqueous methanol solutions using Ti-Zr mixed oxides as photocatalysts under UV irradiation. Catalysts 2019, 9, 938. [CrossRef]

21. Ranjekar, A.M.; Yadav, G.D. Steam reforming of methanol for hydrogen production: A critical analysis of catalysis, processes, and scope. Ind. Eng. Chem. Res. 2021, 60, 89-113. [CrossRef]

22. Pethaiah, S.S.; Sadasivuni, K.K.; Jayakumar, A.; Ponnamma, D.; Tiwary, C.S.; Sasikumar, G. Methanol electrolysis for hydrogen production using polymer electrolyte membrane: A mini-review. Energies 2020, 13, 5879. [CrossRef]

23. Burlica, R.; Shin, K.Y.; Hnatiuc, B.; Locke, B.R. Hydrogen generation by pulsed gliding arc discharge plasma with sprays of alcohol solutions. Ind. Eng. Chem. Res. 2011, 50, 9466-9470. [CrossRef] 
24. Panda, N.R.; Sahu, D. Enhanced hydrogen generation efficiency of methanol using dielectric barrier discharge plasma methodology and conducting sea water as an electrode. Heliyon 2020, 6, e04717. [CrossRef]

25. Bauschlichter, C.W.; Langhoff, S.R.; Walch, S.P. Theoretical study of the bond dissociation energies of methanol. J. Chem. Phys. 1992, 96, 450-454. [CrossRef]

26. Maksyutenko, P.; Rizzo, T.R.; Boyarkin, O.V. A direct measurement of the dissociation energy of water. J. Chem. Phys. 2006, 125, 181101. [CrossRef]

27. Bye, C.A.; Scheeline, A. Electron density profiles in single spark discharges. J. Quant. Spectrosc. Radiative 1995, 53, 75-93. [CrossRef]

28. Cheng, C.; Shi, J.; Du, F.; Zong, S.; Guan, X.; Zhang, Y.; Liu, M.; Guo, L. Simply blending Ni nanoparticles with typical photocatalysts for efficient photocatalytic $\mathrm{H}_{2}$ production. Catal. Sci. Technol. 2019, 9, 7016-7022. [CrossRef]

29. Husin, H.; Pontas, K.; Yunardu, Y.; Salamun, A.; Alam, P.N.; Hasfita, F. Photocatalytic hydrogen production over Ni/La-NaTaO 3 nanoparticles from $\mathrm{NaCl}$-water solution in the presence of glucose as electron donor. ASEAN J. Chem. Eng. 2017, 17, 27-36. [CrossRef]

30. Garay-Rodríguez, L.F.; Murcia-López, S.; Andreu, T.; Moctezuma, E.; Torres-Martínez, L.M.; Morante, J.R. Photocatalytic hydrogen evolution using bi-metallic (Ni/Pt) $\mathrm{Na}_{2} \mathrm{Ti}_{3} \mathrm{O}_{7}$ whiskers: Effect of the deposition order. Catalysts 2019, 9, 285. [CrossRef]

31. Laosiripojana, N.; Assabumrungrat, S. Catalytic steam reforming of methane, methanol, and ethanol over Ni/YSZ: The possible use of these fuels in internal reforming SOFC. J. Power Sources 2007, 163, 943-951. [CrossRef]

32. Li, J.; Mei, X.; Zhang, L.; Yu, Z.; Liu, Q.; Wei, T.; Wu, W.; Dong, D.; Xu, L.; Hu, X. A comparative study of catalytic behaviors of $\mathrm{Mn}, \mathrm{Fe}, \mathrm{Co}, \mathrm{Ni}, \mathrm{Cu}$ and $\mathrm{Zn}$-based catalysts in steam reforming of methanol, acetic acid and acetone. Int. J. Hydrogen. Energy 2020, 45, 3815-3832. [CrossRef]

33. Bobadilla, L.F.; Palma, S.; Ivanova, S.; Dominguez, M.I.; Romero-Sarria, F.; Centeno, M.A.; Odriozola, J.A. Steam reforming of methanol over supported Ni and Ni-Sn nanoparticles. Int. J. Hydrogen. Energy 2013, 38, 6646-6656. [CrossRef]

34. Papavasiliou, J.; Paxinou, A.; Słowik, G.; Neophytides, S.; Avgouropoulos, G. Steam reforming of methanol over nanostructured $\mathrm{Pt} / \mathrm{ToO}_{2}$ and $\mathrm{Pt} / \mathrm{CeO}_{2}$ catalysts for fuel call applications. Catalysts 2018, 8, 544. [CrossRef]

35. Zhang, R.; Huang, C.; Zong, L.; Wang, X.; Cai, J. Hydrogen production from methanol steam reforming over $\mathrm{TiO}_{2}$ and $\mathrm{CeO}_{2}$ pillared clay supported Au catalysts. Appl. Sci. 2018, 8, 176. [CrossRef]

36. Papavasiliou, J.; Słowik, G.; Avgouropoulos, G. Redox behavior of a copper-based methanol reformer for fuel cell applications. Energy Technol. 2018, 6, 1332-1341. [CrossRef]

37. Xu, Z.F.; Raghunath, P.; Lin, M.C. Ab-initio chemical kinetics for the $\mathrm{CH}_{3}+\mathrm{O}(3 \mathrm{P})$ reaction and related isomerization-decomposition of $\mathrm{CH}_{3} \mathrm{O}$ and $\mathrm{CH}_{2} \mathrm{OH}$ radicals. J. Phys. Chem. A 2015, 119, 7404-7417. [CrossRef] [PubMed]

38. Bouallagui, A.; Zanchet, A.; Yazidi, O.; Jaidane, N.; Banares, L.; Senent, M.L.; Garcia-Vela, A. Photodissociation of the $\mathrm{CH}_{3} \mathrm{O}$ and $\mathrm{CH}_{3} \mathrm{~S}$ radical molecules: An ab initio electronic structure study. Phys. Chem. Chem. Phys. 2017, 19, 31245. [CrossRef]

39. Cribb, P.H.; Dove, J.E.; Yamazaki, S. A kinetic study of the pyrolysis of methanol using shock tube and computer simulation techniques. Combust. Flame 1992, 88, 169-185. [CrossRef]

40. Tsang, W. Chemical kinetic data base for combustion chemistry. Part 2. Methanol. J. Phys. Chem. Ref. 1987, 16, 471-508. [CrossRef]

41. Hoyermann, K.; Loftfield, N.S.; Sievert, R.; Wagner, H.G. Mechanism and Rates of the Reactions of $\mathrm{CH}_{3} \mathrm{O}$ and $\mathrm{CH}_{2} \mathrm{OH}$ Radicals with H Atoms. Symp. Int. Combust. Proc. 1981, 18, 831-842. [CrossRef]

42. Jasper, A.W.; Klippenstein, S.J.; Harding, L.B. Theoretical rate coefficients for the reaction of methyl radical with hydroperoxyl radical and for methylhydroperoxide decomposition. Proc. Combust. Inst. 2009, 32, 279-286. [CrossRef]

43. Rhee, T.S.; Brenninkmeijer, C.A.M.; Rockmann, T. Hydrogen isotope fractionation in the photolysis of formaldehyde. Atmos. Chem. Phys. 2008, 8, 1353-1366. [CrossRef]

44. Irdam, E.A.; Kiefer, J.H.; Harding, L.B.; Wagner, A.F. The formaldehyde decomposition chain mechanism. Int. J. Chem. Kinet. 1993, 25, 285-303. [CrossRef]

45. Temps, F.; Wagner, H.G. Rate constants for the reactions of $\mathrm{OH}-$ radicals with $\mathrm{CH}_{2} \mathrm{O}$ and HCO. Ber. Bunsenges. Phys. Chem. 1984, 88, 415-418. [CrossRef]

46. Krasnoperov, L.N.; Chesnokov, E.N.; Stark, H.; Ravishankara, A.R. Unimolecular dissociation of formyl radical, $\mathrm{HCO} \rightarrow \mathrm{H}+\mathrm{CO}$, studied over 1-100 bar pressure range. J. Phys. Chem. A 2004, 108, 1526-11536. [CrossRef]

47. Kaufman, F.; Del Greco, F.P. Fast reactions of OH radicals. Symp. Int. Combust. Proc. 1963, 9, 659-668. [CrossRef]

48. Sangwan, M.; Chesnokov, E.N.; Krasnoperov, L.N. Reaction OH plus OH Studied over the 298-834 K Temperature and 1-100 bar Pressure Ranges. J. Phys. Chem. A 2012, 116, 6282-6294. [CrossRef]

49. Larson, C.W.; Stewart, P.H.; Golden, D.M. Pressure and temperature dependence of reactions proceeding via a bound complex. An approach for combustion and atmospheric chemistry modelers. Application to $\mathrm{HO}+\mathrm{CO} \rightarrow\left[\mathrm{HOCO} \rightarrow \mathrm{H}+\mathrm{CO}_{2}\right.$. Int. J. Chem . Kinet. 1988, 20, 27-40. [CrossRef]

50. Baldwin, R.R.; Jackson, D.; Melvin, A.; Rossiter, B.N. The Second Limit of Hydrogen + Carbon Monoxide + Oxygen Mixtures. Int. J. Chem. Kinet. 1972, 4, 277-292. [CrossRef]

51. Ma, S.; Liu, R. Theoretical studies on the reaction path and dynamics of the reaction $\mathrm{CH}_{3}+\mathrm{H}_{2} \mathrm{O} \rightarrow \mathrm{CH}_{4}+\mathrm{OH}$. Sci. China Ser. B 1996, 39, 37-44.

52. Brouard, M.; Macpherson, M.T.; Pilling, M.J. Experimental and RRKM modeling study of the $\mathrm{CH}_{3}+\mathrm{H}_{\text {and }} \mathrm{CH}_{3}+\mathrm{D}$ Reactions. J. Phys. Chem. 1989, 93, 4047-4059. [CrossRef] 
53. Shannon, T.W.; Harrison, A.G. The reaction of methyl radicals with methyl alcohol. Can. J. Chem. 1963, 41, 2455-2461. [CrossRef]

54. Thynne, J.C.J.; Gray, P. Methoxyl-radical-induced decomposition of methyl formate: Kinetics of methoxyl and methyl radical reactions. Trans. Faraday Soc. 1963, 59, 1149-1155. [CrossRef]

55. Jasper, A.W.; Klippenstein, S.J.; Harding, L.B.; Rustic, B. Kinetics of the reaction of methyl radical with hydroxyl radical and methanol decomposition. J. Phys. Chem. A 2007, 111, 3932-3950. [CrossRef]

56. Kierzkowska-Pawlak, H.; Tracz, P.; Redzynia, W.; Tyczkowski, J. Plasma deposited novel nanocatalysts fof $\mathrm{CO}_{2}$ hydrogenation to methane. J. $\mathrm{CO}_{2}$ Util. 2017, 17, 312-319. [CrossRef]

57. Zhang, L.; Liu, Q.; Aoki, T.; Crozier, P.A. Structural evolution during photocorrosion of $\mathrm{Ni} / \mathrm{NiO}$ core/shell cocatalyst on $\mathrm{TiO}_{2}$. J. Phys. Chem. C 2015, 119, 7207-7214. [CrossRef]

58. Xie, K.; Guo, P.; Xiong, Z.; Sun, S.; Wang, H.; Gao, Y. Ni/NiO hybrid nanostructure supported on biomass carbon for visible-light photocatalytic hydrogen evolution. J. Mater. Sci. 2021, 56, 12775-12788. [CrossRef]

59. Turczyniak, S.; Teschner, D.; Machocki, A.; Zafeiratos, S. Effect of ten surface on the catalytic performance of a Co/CeO 2 ethanol steam reforming catalyst. J. Catal. 2016, 340, 321-330. [CrossRef]

60. Jozwiak, L.; Balcerzak, J.; Tyczkowski, J. Plasma-deposited Ru-based thin films for photoelectrochemical water splitting. Catalysts 2020, 10, 278. [CrossRef]

61. Ulejczyk, B.; Nogal, Ł.; Młotek, M.; Krawczyk, K. Hydrogen production from ethanol using dielectric barrier discharge. Energy 2019, 174, 261-268. [CrossRef] 